\title{
Effect of extraction methods on physicochemical, nutritional, antinutritional, antioxidant and antimicrobial activity of Moringa (Moringa oleifera Lam.) seed kernel oil
}

\author{
B. L. Dinesha ${ }^{1 *}$, Udaykumar Nidoni ${ }^{1}$, C. T. Ramachandra ${ }^{2}$, Nagaraj Naik ${ }^{1}$ and K. B. Sankalpa ${ }^{1}$ \\ ${ }^{1}$ Department of Processing and Food Engineering, College of Agricultural Engineering, University of Agricultural \\ Sciences, Raichur- 584104(Karnataka), INDIA \\ ${ }^{2}$ Department of Agricultural Engineering, College of Agriculture, University of Agricultural Sciences, GKVK, \\ Bengaluru-560 065 (Karnataka), INDIA \\ *Corresponding author. E- mail: dinirbdgtc@gmail.com
}

Received: October 1, 2017; Revised received: October 10, 2017; Accepted: February 2, 2018

\begin{abstract}
The effect of three different extraction methods, namely supercritical $\mathrm{CO}_{2}$, soxhlet and solvent methods on the yield, efficiency, physico-chemical properties, nutritional, anti-nutritional composition, antimicrobial and antioxidant activities of moringa (Moringa oleifera Lam.) seed kernel oil was investigated in this study. Oil extraction for SC- $\mathrm{CO}_{2}$ were $37.76 \mathrm{~g} / 100 \mathrm{~g}$ and $98.43 \%$, observed to be higher than those of soxhlet extraction $(29.12 \mathrm{~g} / 100 \mathrm{~g}$ and $76.29 \%)$, and significantly lower than solvent extraction $(22.12 \mathrm{~g} / 100 \mathrm{~g}$ and $57.99 \%)$. The physico-chemical composition of the oils showed considerable variation among the extraction methods. The $\mathrm{SC}-\mathrm{CO}_{2}$ extracted oil was found to be of superior quality, showing negligible thermal degradation and exhibited significantly $(p<0.01)$ higher nutritional and antioxidant activity and lower anti-nutritional composition than the soxhlet and solvent extracted oils. Oils produced by $\mathrm{SC}-\mathrm{CO}_{2}$ and soxhlet extraction methods had antimicrobial activities higher than solvent extracted oil. SC$\mathrm{CO}_{2}$ extracted oil was found to have maximum number of bioactive compounds (14 compounds) followed by solvent (8 compounds) and soxhlet (4 compounds) extracted oil. The results of the study demonstrated that $\mathrm{SC}-\mathrm{CO}_{2}$ would be a promising process for the extraction of moringa seed kernel oil of premium quality.
\end{abstract}

Keywords: Bioactive compounds, Essential oil, Extraction, Moringa seeds, $\mathrm{SC}-\mathrm{CO}_{2}$

\section{INTRODUCTION}

Moringa (Moringa oleifera Lam.) is generally known to the age-old world, but only currently it has been found again as a multipurpose tree with an awesome variety of potential uses. Moringa owned to the family "Moringaceae" with genus "Moringa Adans" and species "M. oleifera Lam". This species originally comes from North India but now has spread all over the globe in the tropics and subtropics (Enwa et al., 2013). In some parts of the world, $M$. oleifera is called to as the Drumstick tree or the Horse radish tree, Kelor, Marango, Mlonge, Moonga, Mulangay, Nebeday, Saijhan, Sajna or Ben oil tree (Prabhu et al., 2011).

Moringa is an excellent source of nutritional elements reported by Bureau of Plant Industry. Nearly every part of the Moringa plant (leaves, flowers, seeds, roots and bark) can be used as food, medicinal and therapeutic purposes. The seeds can be eaten as such green and roasted; powdered and soaked seeds are used for tea as well as in curries (Anwar et al., 2006). The seeds have powerful coagulative and anti-microbial properties on pathogenic strains of Escherichia coli, Pseudomonas aeruginosa, Streptococcus faecalis, Salmonella typhi and Shigella dysenteriae (Oluduro et al., 2010).

Important bioactive compounds present in the moringa seeds have been used for anti-microbial, antigenotoxic, anti-inflammatory and anti-tumour promoting activities (Prabhu et al., 2011). Excellent source of tocopherols present in the Moringa seed oil, which is considered as the equivalent to olive oil in terms of its chemical properties. It can also be used for edible purpose, rheumatism and gout, purification of blood and enhancing cardiac function (Middleton et al., 2000). Ben oil is another name for Moringa seed kernel oil, is more stable than canola oil, soybean oil, and palm oil when used for frying of foods (Abdulkarim et al., 2005). Ben oil is blended with sunflower oil and soybean oil enhances the oxidative stability of the mixture (Mani et al., 2007). Comparing the physico-chemical properties, nutritional and antinutritional composition, moringa seed oil is contemplate alternative to olive oil and may be used for human consumption (Nguyen et al., 2011).

Moringa seed kernel oil is conventionally produced by hydro and steam distillation and to lower extent by 
solvent extraction method, these extraction methods have more disadvantages (Ali, 1991). Hydro and steam distillation methods are more time consuming processes and high extraction temperatures, causes the degradation of thermal sensitive compounds in the extractant and led to incomplete extraction of oil (Denny, 1988). Unwanted constituents and solvent residues in the final extract are major problems in solvent extraction and it is not possible to obtain solvent free oil. New trends in supercritical carbon dioxide $\left(\mathrm{SC}-\mathrm{CO}_{2}\right)$ extraction technology have shown promising alternative to conventional extraction methods. $\mathrm{SC}-\mathrm{CO}_{2}$ has been found to produce extracts with waxes, pigments, anti-nutritional constituents free from chemical alterations influenced by temperature, moisture content, and solvent free residues, undesirable compounds such as organic and inorganic salt, sugars, amino acids and tannins (Razazadeh et al., 2008; Da Porto et al., 2009). Extraction methods can have influence on the yield, efficiency, physico-chemical properties, nutritional and antinutritional composition and biological activities of moringa seed kernel oil, particularly antioxidant and antimicrobial activities (Topal et al., 2008; Danh, et al. 2011).The objective of this investigation was to study the effect of different extraction methods, namely solvent extraction using methanol, soxhlet extraction with nhexane and supercritical $\mathrm{CO}_{2}$ extraction on oil yield, efficiency, physico-chemical properties, nutritional and antinutritional composition and antimicrobial activities of moringa (Moringa oleifera Lam.) seed kernel oil to recommend the best method of extraction for quality oil.

\section{MATERIALS AND METHODS}

Raw materials: Moringa seeds (PKM-1) were procured from local market in Raichur, Karnataka (India). The shells were removed manually and the kernels were ground by using laboratory hammer mill to obtain fine powder of $0.16 \mathrm{~mm}$ particle size (Nguyen et al., 2011).

Solvent extraction: Moringa seed kernel oil was extracted in $150 \mathrm{~mL}$ methanol in five hundred milliliter round bottomed flask for $72 \mathrm{~h}$ at room temperature (Oluduro et al., 2010).

Soxhlet extraction: The extraction was carried out at $85{ }^{\circ} \mathrm{C}$ temperature for $90 \mathrm{~min}$ extraction time and n-hexane was used as solvent in Soxhlet apparatus (Malapit, 2010).

SC-CO $\mathrm{O}_{2}$ extraction: Oil was extracted by $\mathrm{SC}-\mathrm{CO}_{2}$ extraction unit (Thar; SFE 500). Cooling of different zones in the $200 \mathrm{~mL}$ capacity extraction vessel was done by deionized water at $5{ }^{\circ} \mathrm{C}$. The optimized parameters selected for the study were $\mathrm{SC}-\mathrm{CO}_{2}$ pressure of $200 \mathrm{bar}$, temperature of $50{ }^{\circ} \mathrm{C}$ and dynamic extraction time of $90 \mathrm{~min}$ (Liza et al., 2010). Fifty grams of moringa seed kernel powder was placed into the extractor vessel. The flow rates of $\mathrm{SC}-\mathrm{CO}_{2}$ and cosolvent (ethanol) were maintained at 20 and $2 \mathrm{~g} / \mathrm{min}$, respectively (Pradhan et al., 2010). Static extraction process for $30 \mathrm{~min}$ was used. The dynamic extraction time (90 $\mathrm{min}$ ) was started after attaining desired pressure and temperature, by adjusting the exit valve (ABPR-valve) of the $\mathrm{SC}-\mathrm{CO}_{2}$ extraction system. During the static extraction time the sample was allowed to soak in $\mathrm{CO}_{2}$ and co-solvent in order to equilibrate the mixture at desired pressure and temperature. Carbon dioxide carried the crude extract flooded out of the extraction vessel and then into a collection vessel during the dynamic extraction. After completion of dynamic extraction time carbon dioxide was separated in the collection vessel and then flooded through the vent connected to the fume hood (Palafox et al., 2012).

Extraction yield and efficiency: The extraction yield and extraction efficiency of $\mathrm{SC}-\mathrm{CO}_{2}$ extracted moringa seed kernel oil were determined according to the methods described by Liza et al. (2010); Olawale. (2012).

Physico-chemical properties: Density and specific gravity of the extracted oil were determined using the method described by Adejumo et al. (2013) and the colour values $\left(L^{*}, a^{*}\right.$ and $\left.b^{*}\right)$ were measured by using Hunter lab colourimeter (Cho et al., 2010). The $\mathrm{pH}$, absorbance (at $270 \mathrm{~nm}$ ) and refractive index were measured according to the procedure explained by Orhevba et al. (2013); Ogbunugafor et al. (2011). Acid value, saponification value, iodine value and peroxide value of oil samples were determined by using respective standard methods (AOAC, 1990).

Nutritional and anti-nutritional composition: Total phenol, flavonoid, carotenoid, sterol, tocopherol, oleic acid and antioxidant capacity were analyzed according to methods described by Bhatnagar and Krishna, (2013); Ogbunugafor et al. (2011); Dauqan et al. (2011a); Sabir et al. (2003); Dauqan et al. (2011b); Nilani et al. (2012); Nabasree and Bratati, (2007). Anti -nutritional constituents viz., tannins, saponins and phytates present in the moringa seed kernel oil were determined by the methods described by Inuwa et al. (2011), Jaffe, (2003), Anhwange et al. (2004) and Lucas and Markaka, (1975).

Bioactive compounds: Qualitative analysis of bioactive compounds present in the moringa seed kernel oil was analysied by GC-MS (Shimadzu Make QP-2010 with non-polar $60 \mathrm{M}$ RTX 5MS column). Carrier gas used was Helium and the initial temperature of oven was set for $400{ }^{\circ} \mathrm{C}$ and held for $3 \mathrm{~min}$ and the final temperature of the oven was maintained at $480{ }^{\circ} \mathrm{C}$ with rate at $100{ }^{\circ} \mathrm{C} / \mathrm{min} .2 \mu \mathrm{L}$ of oil was injected with split mode of 1:50 ratio. Mass spectra were recorded in range of 35-650 amu, with $70 \mathrm{eV}$ electron impact ionization energy. The total running time of $45 \mathrm{~min}$ was used for each sample. The volatile compounds present in oil were indicated by comparing the retention times of chromatogram peaks using quadra pole detector with NIST library to correlate the relative retention time indices. Quantitative determinations were made by matching the respective peak areas to TIC areas 
from the GC-MS (Mahadkar et al., 2013).

Free radical scavenging activity: Free radical scavenging activity of moringa seed kernel oil against 1,1diphenyl-2-picrylhydrazly (DPPH) was determined by the method reported by Adesugen et al. (2008).

Antimicrobial activity: Antimicrobial sensitivity was tested for bacteria and fungi namely, Escherichia coli, Pseudomonas aeruginosa, Staphylococcus aureus, Bacillus subtilis, Mucor and Aspergillus by using disc agar diffusion technique described by Bauer et al. (1966); Cakir et al. (2004).

Statistical analysis: Statistical analysis was performed using SPSS (Statistical Package for Social Sciences) software package. The current version of 2015 was used and experimental results were computed for the mean, standard deviation (SD) and standard error mean (SEM). All the experiments were performed at least three times and were subjected to two-way analysis of variance.

\section{RESULTS AND DISCUSSION}

Effect of different extraction methods on extraction yield and efficiency of Moringa seed kernel oil: Extraction yield, efficiency and physico-chemical properties of moringa seed kernel oil extracted by three dif- ferent methods are presented in Table 1. $\mathrm{SC}-\mathrm{CO}_{2}$ extraction recorded highest extraction yield (37.76 $\mathrm{g} / 100 \mathrm{~g}$ ) and efficiency (98.43\%), followed by soxhlet (29.12 g/100g and 76.29\%), while solvent extraction gave the lowest yield $(22.12 \mathrm{~g} / 100 \mathrm{~g})$ and efficiency $(57.99 \%)$. These results were in agreement with the results reported by Danh et al. (2011) for extraction of Lavanders essential oil.

The oil yield obtained from solvent extraction method was found lower compared to the $\mathrm{SC}-\mathrm{CO}_{2}$ extraction method. The differences in extraction yield among three methods are significant due to differences in operating conditions (time, pressure, temperature and particulate size) and the constituents present in the oil. Furthermore, $\mathrm{SC}-\mathrm{CO}_{2}$ was drived at a lower temperature than the other methods. In overall, the extraction of Moringa seed kernel oil by $\mathrm{SC}-\mathrm{CO}_{2}$ showed efficient and it could be an excellent alternative to traditional extraction method for achieving higher in terms of yield and extraction efficiency.

Effect of different extraction methods on phsicochemical properties of Moringa seed kernel oil: From the Table 1, it is clearly demonstrated by highest oil density and specific gravity of $0.984 \mathrm{~g} / \mathrm{cc}$ and 0.998

Table 1. Effect of different extraction methods on yield, efficiency and physico-chemical properties of Moringa seed kernel oil.

\begin{tabular}{|c|c|c|c|c|c|}
\hline \multicolumn{6}{|c|}{ Extraction methods } \\
\hline & Solvent & Soxhlet & $\mathrm{SC}-\mathrm{CO}_{2}$ & Std. Deviation & Std. Error Mean \\
\hline Extraction yield (g/100g) & 22.13 & 29.12 & 37.76 & 7.830 & 4.520 \\
\hline Extraction efficiency (\%) & 57.99 & 76.29 & 98.43 & 20.250 & 11.692 \\
\hline \multicolumn{6}{|l|}{ Physical properties } \\
\hline Density $(\mathrm{g} / \mathrm{cc})$ & 0.907 & 0.912 & 0.984 & 0.043 & 0.025 \\
\hline Specific gravity & 0.914 & 0.92 & 0.998 & 0.047 & 0.027 \\
\hline $\mathrm{pH}$ & 5.80 & 4.10 & 6.25 & 1.134 & 0.655 \\
\hline Refractive index & 1.415 & 1.461 & 1.487 & 0.036 & 0.021 \\
\hline Absorbance (at 270) nm & 0.02 & 0.022 & 0.027 & 0.004 & 0.002 \\
\hline $\mathrm{L}^{*}$ value & 5.87 & 9.06 & 3.40 & 2.838 & 1.638 \\
\hline $\mathrm{a}^{*}$ value & -0.93 & -0.75 & -0.54 & 0.195 & 0.113 \\
\hline $\mathrm{b}^{*}$ value & 1.11 & 1.87 & 1.08 & 0.448 & 0.258 \\
\hline \multicolumn{6}{|l|}{ Chemical properties } \\
\hline $\mathrm{AV}$ (mg of $\mathrm{KOH} / \mathrm{g}$ of oil) & 3.71 & 3.75 & 2.80 & 0.537 & 0.310 \\
\hline $\mathrm{SV}$ (mg of KOH/g of oil) & 188.25 & 188.05 & 185.66 & 1.441 & 0.832 \\
\hline IV $(\mathrm{g} / \mathrm{mol})$ & 60.25 & 61.15 & 66.71 & 3.499 & 2.020 \\
\hline $\mathrm{PV}$ (meq of O2/ kg of oil) & 60.46 & 61.15 & 98.06 & 21.512 & 12.420 \\
\hline
\end{tabular}

Table 2. Effect of different extraction methods on nutritional and anti-nutritional composition of Moringa seed kernel oil.

\begin{tabular}{|c|c|c|c|c|c|}
\hline \multirow{2}{*}{ Composition } & \multicolumn{5}{|c|}{ Extraction methods } \\
\hline & Solvent & Soxhlet & $\mathrm{SC}-\mathrm{CO}_{2}$ & Std. Deviation & Std. Error Mean \\
\hline \multicolumn{6}{|l|}{ Nutritional compositions } \\
\hline Total phenols (mg GAE/g) & 40.12 & 40.18 & 44.71 & 2.633 & 1.520 \\
\hline Total flavanoids (mg RE/g) & 16.82 & 16.9 & 18.25 & 0.804 & 0.464 \\
\hline Total carotenoids (ppm) & 15.26 & 15.72 & 17.06 & 0.935 & 0.540 \\
\hline Total sterols (ppm) & 837.85 & 880.57 & 984.17 & 75.241 & 43.441 \\
\hline Total tocopherols (ppm) & 77.81 & 79.12 & 92.26 & 7.991 & 4.614 \\
\hline Oleic acid $(\%)$ & 69.25 & 69.77 & 73.84 & 2.513 & 1.451 \\
\hline Total antioxidents (mg AAE/g) & 37.91 & 38.22 & 36.42 & 0.962 & 0.556 \\
\hline \multicolumn{6}{|l|}{ Anti-nutritional composition } \\
\hline Tannins (\%) & 9.10 & 9.12 & 6.13 & 1.721 & 0.993 \\
\hline Saponins (\%) & 0.32 & 0.35 & 0.26 & 0.046 & 0.026 \\
\hline Phytate (\%) & 11.36 & 11.49 & 3.09 & 4.813 & 2.779 \\
\hline
\end{tabular}


B.L. Dinesha et al. / J. Appl. \& Nat. Sci. 10(1): 287 - 295 (2018)

Table 3. Effect of different extraction methods on antimicrobial activity of Moringa seed kernel oils.

\begin{tabular}{|c|c|c|c|c|c|}
\hline \multirow{3}{*}{ Microorganisms } & \multicolumn{5}{|c|}{ Inhibition zone diameter (mm) } \\
\hline & \multicolumn{5}{|c|}{ Oil extraction methods } \\
\hline & Solvent & Soxhlet & $\mathrm{SC}-\mathrm{CO}_{2}$ & Std. Deviation & Std. Error Mean \\
\hline \multicolumn{6}{|l|}{ Gram+ } \\
\hline Bacillus cereus & 6.51 & 8.56 & 11.52 & 2.519 & 1.454 \\
\hline Staphylococcus aureus & 6.78 & 6.85 & 8.66 & 1.066 & 0.615 \\
\hline \multicolumn{6}{|l|}{ Gram- } \\
\hline Escherichia coli & 0 & 0 & 9.54 & 5.508 & 3.180 \\
\hline Pseudomonas aeruginosa & 0 & 0 & $\mathbf{0}$ & 0.000 & 0.000 \\
\hline \multicolumn{6}{|l|}{ Fungy } \\
\hline Mucor species & 10.32 & 11.41 & 12.56 & 1.120 & 0.647 \\
\hline Aspergillus species & 8.77 & 9.46 & 12.23 & 1.831 & 1.057 \\
\hline
\end{tabular}

Table 4. Effect of different extraction methods on free radical scavenging activity of Moringa seed kernel oils.

\begin{tabular}{lllllll}
\hline $\begin{array}{l}\text { Extraction } \\
\text { methods }\end{array}$ & \multicolumn{2}{l}{ Concentration of extract $(\boldsymbol{\mu g} / \mathbf{m L})$} & \multicolumn{2}{l}{$\begin{array}{l}\text { Std. Devia- } \\
\text { tion }\end{array}$} & $\begin{array}{l}\text { Std. } \\
\text { Mean }\end{array}$ \\
\cline { 2 - 7 } & $\mathbf{5 0}$ & $\mathbf{1 0 0}$ & $\mathbf{1 5 0}$ & $\mathbf{2 0 0}$ & 1.83308 & 0.91654 \\
\hline Solvent & $47.83 \pm 0.02$ & $49.01 \pm 0.01$ & $50.12 \pm 0.05$ & $52.14 \pm 0.02$ & 7.05 \\
Soxhlet & $48.15 \pm 0.01$ & $52.97 \pm 0.04$ & $60.12 \pm 0.06$ & $70.01 \pm 0.06$ & 9.50293 & 4.75147 \\
SC-CO & $\mathbf{8 0 . 6 0} \pm \mathbf{0 . 0 7}$ & $\mathbf{8 2 . 0 2} \pm \mathbf{0 . 0 6}$ & $\mathbf{8 3 . 2 8} \pm \mathbf{0 . 0 2}$ & $\mathbf{8 3 . 8 0} \pm \mathbf{0 . 0 2}$ & $\mathbf{1 . 4 2 7 8 5}$ & $\mathbf{0 . 7 1 3 9 3}$ \\
\hline
\end{tabular}

were recorded in $\mathrm{SC}-\mathrm{CO}_{2}$ followed by soxhlet extraction method $(0.912 \mathrm{~g} / \mathrm{cc}$ and 0.920$)$, whereas the lowest of $0.907 \mathrm{~g} / \mathrm{cc}$ and 0.914 were recorded in solvent extraction method. According to Adejumo et al. (2012), the density and specific gravity of oil decreased as the temperature increased. This might be due to the fact that the oil seeds frequently lose some of its characteristics when exposed to higher temperatures, resulting decline in its density and specific gravity in case of solvent $\left(85^{\circ} \mathrm{C}\right)$ and soxhlet $\left(85^{\circ} \mathrm{C}\right)$ extraction methods on the other side, in case of $\mathrm{SC}-\mathrm{CO}_{2}$ extraction method the density and specific gravity of oil increased due to lower extraction temperature $\left(50^{\circ}\right.$ C) used. The values of specific gravity of the oil samples were within the range of $0.90-1.16$ for edible oil given by $\mathrm{FAO} / \mathrm{WHO}$, (2009). These values were in good agreement with the results reported by Belewu et al. (2010); Tint and Mya, (2009) for Jatropha curcas seed oil. $\mathrm{SC}-\mathrm{CO}_{2}$ extraction yielded the oil of nearly neutral $\mathrm{pH}$ value (6.25), followed by solvent extraction shown slightly acidic (5.80) and soxhlet extraction highly acidic $\mathrm{pH}$ (4.10). This might be due to the enzymatic activity of oil at higher temperature (Wang et al., 2010). The lowest refractive index was obtained for solvent extraction (1.415), followed by soxhlet extraction (1.461) and the highest value of 1.487 was obtained in $\mathrm{SC}-\mathrm{CO}_{2}$ extracted oil.

The maximum colour value $L^{*}$ of the oil was found to be 3.40 for $\mathrm{SC}-\mathrm{CO}_{2}$ followed by soxhlet (9.06) and solvent extraction (5.87). The colour values of $a^{*}$ were observed to be $-0.54\left(\mathrm{SC}-\mathrm{CO}_{2}\right),-0.75$ (Soxhlet) and 0.93 (Solvent extraction). Similarly $b^{*}$ values obtained 1.08 for $\mathrm{SC}-\mathrm{CO}_{2}, 1.87$ for soxhlet and 1.11 for solvent. Similar trends have been reported for $\mathrm{SC}-\mathrm{CO}_{2}$ extracted ginseng seed oil (Orhevba et al., 2013). The colour values were found minimum in $\mathrm{SC}-\mathrm{CO}_{2}$ extracted oil compared to the other two extraction methods. This might be due to higher temperature of $85^{\circ} \mathrm{C}$ applied in soxhlet extraction that lowered the specific gravity thereby the color of the oil. These values are in agreement with the earlier findings of Rahman et al. (2012); Orhevba et al. (2013). The color intensity of the vegetable oils depends mainly on the presence of pigments such as chlorophyll, which is effectively removed during the degumming, refining and bleaching process. For edible and domestic purposes the vegetable oils with minimum values of color index are more suitable (Anwar et al., 2006).

The chemical properties of oil are the most important properties that determine the original conditions of the oil. Acid and peroxide values are valuable indices for the oil quality measurement. The iodine and saponification values indicate the degree of unsaturation of fatty acids in the oil. The acid and saponification values of the $\mathrm{SC}-\mathrm{CO}_{2}$ extracted oil were significantly lower $(185.66 \mathrm{mg}$ of $\mathrm{KOH} / \mathrm{g}$ of oil) than the soxhlet (188.05 mg of $\mathrm{KOH} / \mathrm{g}$ of oil) and solvent $(188.25 \mathrm{mg}$ of $\mathrm{KOH} / \mathrm{g}$ of oil) extracted oil. Similarly, more significant differences found in iodine and peroxide values of $\mathrm{SC}-\mathrm{CO}_{2}$ oil compared to soxhlet and solvent extracted oil. The acid values of $\mathrm{SC}-\mathrm{CO}_{2}$ extracted Moringa seed kernel oil was found within the range specified by FAO/WHO (2009).

Effect of extraction methods on nutritional and anti -nutritional composition in Moringa seed kernel oil: Moringa oleifera seed kernel oil extraction had been studied by several authors viz, Mani et al. (2007); Nguyen et al. (2011); Palafox et al. (2012); Premi and Sharma (2013), Zhao and Zhang (2013). However, none of these investigations reported the detailed the comparison of oil obtained by $\mathrm{SC}-\mathrm{CO}_{2}$ and other conventional extraction methods for moringa seed kernel oil. Quantitative analysis was made by observing the nutritional and anti-nutritional composition of seed kernel oil, and the results are depicted in Table. 2. It is observed from the results that the total phenols (44.71 
Table 5. Effect of different extraction methods on retention of bioactive compounds in Moringa seed kernel oil.

\begin{tabular}{|c|c|c|c|c|c|}
\hline $\begin{array}{l}\text { Extraction } \\
\text { method }\end{array}$ & Compound analyzed & Molecular formula & Mol. Wt. (In grams) & $\begin{array}{l}\text { Retention } \\
\text { time }\end{array}$ & $\begin{array}{l}\text { \% Area of } \\
\text { peak }\end{array}$ \\
\hline \multirow[t]{8}{*}{ Solvent } & Cycloheptasiloxane & $\mathrm{C}_{14} \mathrm{H}_{42} \mathrm{O}_{7} \mathrm{Si}_{7}$ & 518 & 13.509 & 2.66 \\
\hline & Cyclooctasiloxane & $\mathrm{C}_{16} \mathrm{H}_{48} \mathrm{O}_{8} \mathrm{Si}_{8}$ & 592 & 16.148 & 1.35 \\
\hline & Hexadecanoic acid & $\mathrm{C}_{17} \mathrm{H}_{34} \mathrm{O}_{2}$ & 270 & 18.651 & 2.85 \\
\hline & n-Hexadecoic acid & $\mathrm{C}_{16} \mathrm{H}_{32} \mathrm{O}_{2}$ & 256 & 19.097 & 18.16 \\
\hline & 9,12-Octadecadienoic acid, & $\mathrm{C}_{19} \mathrm{H}_{34} \mathrm{O}_{2}$ & 294 & 20.262 & 1.65 \\
\hline & Octadecanoic acid & $\mathrm{C}_{18} \mathrm{H}_{36} \mathrm{O}_{2}$ & 284 & 20.961 & 5.32 \\
\hline & 9-Octadecenoic acid & $\mathrm{C}_{18} \mathrm{H}_{34} \mathrm{O}_{2}$ & 282 & 22.457 & 1.01 \\
\hline & Eicosanoic acid & $\mathrm{C}_{20} \mathrm{H}_{40} \mathrm{O}_{2}$ & 312 & 22.702 & 0.65 \\
\hline \multirow[t]{4}{*}{ Soxhlet } & Tetradecanoic acid & $\mathrm{C}_{14} \mathrm{H}_{28} \mathrm{O}_{2}$ & 228 & 17.031 & 4.23 \\
\hline & n-Hexadecanoic acid & $\mathrm{C}_{16} \mathrm{H}_{32} \mathrm{O}_{2}$ & 256 & 19.086 & 29.69 \\
\hline & Octadecadienoic acid & $\mathrm{C}_{19} \mathrm{H}_{34} \mathrm{O}_{2}$ & 294 & 20.653 & 42.75 \\
\hline & Octadecanoic acid & $\mathrm{C}_{18} \mathrm{H}_{36} \mathrm{O}_{2}$ & 284 & 20.942 & 8.35 \\
\hline \multirow[t]{14}{*}{$\mathrm{SC}-\mathrm{CO}_{2}$} & Oxiraneethanol & $\mathrm{C}_{8} \mathrm{H}_{16} \mathrm{O}_{4}$ & 176 & 8.188 & 1.12 \\
\hline & Nonanoic acid & $\mathrm{C}_{10} \mathrm{H}_{18} \mathrm{O}_{3}$ & 186 & 12.755 & 1.59 \\
\hline & $\begin{array}{l}\text { 3-Isopropoxy-1,1,1,7,7,7- } \\
\text { hexamethyl-3,5,5- } \\
\text { tris(trimethylsiloxy) } \\
\text { tetrasiloxane }\end{array}$ & $\mathrm{C}_{18} \mathrm{H}_{52} \mathrm{O}_{7} \mathrm{Si}_{7}$ & 576 & 14.63 & 13.51 \\
\hline & Propanoic acid & $\mathrm{C}_{16} \mathrm{H}_{30} \mathrm{O}_{4}$ & 286 & 15.498 & 2.35 \\
\hline & Cyclooctasiloxane & $\mathrm{C}_{16} \mathrm{H}_{48} \mathrm{O}_{8} \mathrm{Si}_{8}$ & 592 & 16.917 & 5.4 \\
\hline & Hexahydropseudoionone & $\mathrm{C}_{13} \mathrm{H}_{26} \mathrm{O}$ & 198 & 18.583 & 0.35 \\
\hline & Z-5-Octadecen-1-ol acetate & $\mathrm{C}_{20} \mathrm{H}_{38} \mathrm{O}_{2}$ & 310 & 18.635 & 0.53 \\
\hline & Heptasiloxane & $\mathrm{C}_{14} \mathrm{H}_{44} \mathrm{O}_{6} \mathrm{Si}_{7}$ & 504 & 18.722 & 1.42 \\
\hline & Hexadecanoic acid & $\mathrm{C}_{17} \mathrm{H}_{34} \mathrm{O}_{2}$ & 270 & 19.35 & 15.29 \\
\hline & n-Hexadecanoic acid & $\mathrm{C}_{16} \mathrm{H}_{32} \mathrm{O}_{2}$ & 256 & 19.73 & 9.82 \\
\hline & 9,12-Octadecadienoic acid & $\mathrm{C}_{19} \mathrm{H}_{34} \mathrm{O}_{2}$ & 294 & 20.952 & 11.15 \\
\hline & Phytol & $\mathrm{C}_{20} \mathrm{H}_{40} \mathrm{O}$ & 296 & 21.217 & 33.07 \\
\hline & Octadecanoic acid & $\mathrm{C}_{22} \mathrm{H}_{44} \mathrm{O}_{4}$ & 372 & 21.601 & 3.94 \\
\hline & 11,14-Eicosadienoic acid & $\mathrm{C}_{21} \mathrm{H}_{38} \mathrm{O}_{2}$ & 322 & 21.748 & 0.47 \\
\hline
\end{tabular}

$\mathrm{mg}$ GAE/g) extracted by $\mathrm{SC}-\mathrm{CO}_{2}$ was the highest among the total phenols obtained from other two extraction methods. Total flavonoids and total carotenoid in $\mathrm{SC}-\mathrm{CO}_{2}$ extracted oil were $18.25(\mathrm{mg} \mathrm{RE} / \mathrm{g})$ and $17.06(\mathrm{ppm})$, respectively, whereas, soxhlet extracted oil had $16.9 \mathrm{mg} \mathrm{RE} / \mathrm{g}$ of total flavonoids and 15.72 ppm of total carotenoids and $16.82 \mathrm{mg} \mathrm{RE} / \mathrm{g}$ and 15.26 ppm were found in solvent extracted oil. These results are in contrast with the findings of Oliveira et al. (2013) who reported similar results on supercritical fluid extraction of oil from passion fruit seeds and its processing residue (cake), whereas similar variation in TPC from 21 to $28 \mathrm{mg}$ of GAE/ g extract has been reported. The occurrence of higher flavonoids in moringa oil would increase the economic health prospective of the oil as the earlier discovery suggested that flavonoids carry antioxidant activity through scavenging or chelating activity and play inhibitory role in cancer and heart disease (Ogbunugafor et al., 2011). Total carotenoids content obtained from $\mathrm{SC}-\mathrm{CO}_{2}$ extraction $(15.26 \mathrm{ppm})$ was more compared to soxhlet extraction $(15.75 \mathrm{ppm})$.

It was observed that the essential oil extracted using $\mathrm{SC}-\mathrm{CO}_{2}$ method exhibited a higher amount of total sterols (984.17 ppm), whereas soxhlet and solvent ex- tracted oil had lower values of $880.57 \mathrm{ppm}$ and 837.85 ppm, respectively. The extraction methods differed significantly for total tocoperols and it was noted that the $\mathrm{SC}-\mathrm{CO}_{2}$ method yielded oil with a total tocoperols of $92.26 \mathrm{ppb}$ followed by soxhlet extraction (79.12 $\mathrm{ppb}$ ) and solvent extraction (77.81 ppb). These results are comparable with the earlier findings reported by Tsaknis et al. (1999); Palafox, (2012) reported for Moringa oleifera variety mbololo seed oil.

The oleic acid content varied in $M$. oleifera essential oil extracted by different methods. It was found that the $\mathrm{SC}-\mathrm{CO}_{2}$ extracted oil possessed more oleic acid with a value of $73.84 \%$ as compared to other two methods namely, soxhlet extraction $(69.77 \%)$ and solvent extraction (69.25\%). Corn, sunflower and canola oils are reported as high oleic acid vegetable oils and have have enough oxidative stability during frying of foods. Oleic acid rich oils have low saturated fatty acid levels, therefore Moringa seed kernel oil with high oleic oils could be a healthier substitute for partially hydrogenated vegetable oils (Petukhov et al., 1999; Abdulkarim et al., 2009 and Dinesha et al., 2016).

A wide range of total antioxidants were observed in different extraction methods. Oil obtained by $\mathrm{SC}-\mathrm{CO}_{2}$ extraction method (36.42 mg AAE/g) contained higher 
amounts than soxhlet (38.22 $\mathrm{mg} \mathrm{AAE} / \mathrm{g}$ ) and solvent (37.91 mg AAE/g) extracted oil. These results indicating the occurrence of large quantities of total antioxidants in moringa seed kernel oil have not been reported previously. These values are in good agreement with the findings of Ogbunugafor et al. (2011). Higher total antioxidant capacity of $\mathrm{SC}-\mathrm{CO}_{2}$ extracted oil might be due to higher solubility power of $\mathrm{SC}-\mathrm{CO}_{2}$ compared to other two solvents. The hexane extracts did not exhibit antioxidant activity by DPPH and the same results have been reported by Oliveira et al. (2013).

The results showed that the lowest amounts of antinutritional contents namely, tannin, saponin and phytate in the extracted oil were found to be the highest in $\mathrm{SC}-\mathrm{CO}_{2}$ extracted oil $(6.13,0.26$ and $3.09 \%)$ followed by soxhlet method $(9.12,0.35$ and $11.49 \%)$ and solvent method (9.10, 0.32 and $11.36 \%)$. These findings are in agreement with the results of previous studies reported by Mbah et al. (2012) on effect of cooking methods on antinutritional contents of Moringa oleifera seeds. From the findings of this study, $\mathrm{SC}-\mathrm{CO}_{2}$ extracted oil contained lower concentrations of the analyzed anti-nutritional factors compared to soxhlet and solvent extraction methods due to higher pressure applied in $\mathrm{SC}-\mathrm{CO}_{2}$ extraction method and hence dissolution of anti-nutritional constituents in the $\mathrm{SC}-\mathrm{CO}_{2}$ was higher than other two solvents (Couto et al., 2009). Hence, SC- $\mathrm{CO}_{2}$ extracted moringa oil conformed lower amount of anti-nutritional composition and it might be recommended as cooking oil by blending with other edible oils.

Effect of different extraction methods on antimicrobial activity of Moringa seed kernel oil: Moringa seed kernel oil presented excellent antibacterial and antifungal activities against the test organisms as shown in Table 3. Diameter zone of inhibition (DZI) for gram-positive bacterium viz., Bacillus cereus and Staphylococcus aureus was found higher in $\mathrm{SC}-\mathrm{CO}_{2}$ $(11.52$ and $8.66 \mathrm{~mm})$ followed by soxhlet $(8.56$ and $6.85 \mathrm{~mm})$ and solvent $(6.51$ and $6.78 \mathrm{~mm})$ extracted oil. Similar results have been reported by Bukar et al. (2010); Talreja, (2010). Gram-negetive bacteria (Escherichia coli and Pseudomonas aeruginosa) did not show DZI. DZI was not observed for the Moringa seed kernel oil extracted by all the three methods where as DZI of $9.54 \mathrm{~mm}$ for Escherichia coli was noticed in $\mathrm{SC}-\mathrm{CO}_{2}$ extracted oil.

Results revealed that, among the bacteria, moringa seed kernel extract was effective against gram positive bacteria such as Bacillus cereus and Staphylococcus aureus, whereas it was not effective against gram negative bacteria such as Escherichia coli and Pseudomonas aeruginosa. It might be due to variation in the peptidoglycon layer present in the cell wall of gram negative bacterial cell (Bukar et al., 2010). Fungal pathogens like Mucor species exhibited more DZI
$(10.32,11.41$ and $12.56 \mathrm{~mm})$ and Aspergillus species exhibited lower DZI (8.77, 9.46 and $12.23 \mathrm{~mm})$.

Moringa seed kernel extract had strong inhibitory effect against Bacillus cereus, Staphylococcus aureus, Mucor species and Aspergillus species. Whereas, it showed less effective against $E$. coli and $P$. aerugino$s a$. This suggested that, the $\mathrm{SC}-\mathrm{CO}_{2}$ extracted moringa seed kernel extract might be used for treatment of infections caused by these organisms except $E$. coli and $P$. aeruginosa, which were found to be resistant to the activity of the $\mathrm{SC}-\mathrm{CO}_{2}$ extracted moringa seed kernel extract (Abalaka et al., 2012).

The antimicrobial activity of $M$. oleifera seed extract might be due to the presence of an phytochemicals. Bukar et al. (2010) and Suarez et al. (2003) identified, the presence of a short polypeptide named 4 ( $\alpha$-Lrhamnosyloxy) benzyl- isothiocyanate in moringa seeds. The peptide might act directly on microorganisms and might result in growth inhibition by destroying the cell membrane (Abalaka et al., 2012).

Effect of different extraction methods on free radical scavenging activity in Moringa seed kernel oil: Free radical scavenging activity of different extraction methods for moringa seed kernel oil is depicted in Table 4. Free radical scavenging activity was more in SC$\mathrm{CO}_{2}$ extracted moringa oil $(80.60 \pm 0.07,82.02 \pm 0.06$, $83.28 \pm 0.02$ and $83.80 \pm 0.02$ at $50,100,150$ and $200 \mu \mathrm{g} /$ $\mathrm{mL})$ than the solvent $(47.83 \pm 0.02,49.01 \pm 0.01$, $50.12 \pm 0.05$ and $52.14 \pm 0.02$ at $50,100,150$ and $200 \mu \mathrm{g} /$ $\mathrm{mL})$ and soxhlet extracted oil $(48.15 \pm 0.01,52.97 \pm 0.04$, $60.12 \pm 0.06$ and $70.01 \pm 0.06$ at 50,100,150 and $200 \mu \mathrm{g} /$ $\mathrm{mL})$. The percentage inhibition of DPPH radicals increased with increasing concentration of oil. This might be due to the quenching of proton free radicals and decrease in absorbance of DPPH-oil mixture, and the results are in agreement with the findings of Asokkumar et al. (2009). This is in accordance with previous discovery that suggested the flavonoids carry antioxidant activity through scavenging or chelating have deterrent role in cancer and heart disease (Middleton et al., 2000). Consequently, the significance of the antioxidant components present in the moringa seed kernel oil used to maintain health. Moringa seed kernel essential oil could be the future trend moving towards using foods as medicine in controlling various chronic diseases.

Effect of different extraction methods on retention of Bioactive compounds in Moringa seed kernel oil: The comparison between the major bioactive compounds present in the essential oils obtained by different extraction methods shown in Table 5. From these results, it is seen that the retention of bioactive compounds in oil was influenced by the extraction method used. The oil obtained by solvent extraction method showed the presence of Cycloheptasiloxane (2.66\%), Cyclooctasiloxane (1.35\%), Hexadecanoic acid $(2.85 \%)$, n-Hexadecoic acid $(18.16 \%)$, 9,12- 
Octadecadienoic acid (1.65\%), Octadecanoic acid $(5.32 \%)$, 9-Octadecenoic acid (1.01\%) and Eicosanoic acid $(0.65 \%)$. Soxhlet extracted oil represented four compounds viz., Tetradecanoic acid (4.23\%), nHexadecanoic acid (29.69\%), Octadecadienoic acid (42.75) and Octadecanoic acid (8.35\%), whereas SC$\mathrm{CO}_{2}$ extracted oil showed highest number of compounds viz., Oxiraneethanol (1.12\%), Nonanoic acid (1.59\%), 3-Isopropoxy-1,1,1,7,7,7- hexamethyl-3,5,5tris(trimethylsiloxy) tetrasiloxane (13.51\%), Propanoic acid (2.35\%), Cyclooctasiloxane (5.40), Hexahydropseudoionone (0.35), Z-5-Octadecen-1-ol acetate (0.53), Heptasiloxane (1.42), Hexadecanoic acid (15.29), n-Hexadecanoic acid (9.82), 9,12Octadecadienoic acid (11.15), Phytol (33.07), Octadecanoic acid (3.94) and 11,14-Eicosadienoic acid $(0.47 \%)$. This higher bioactive compounds rettion in $\mathrm{SC}-\mathrm{CO}_{2}$ extracted oil might be due to the lower temperature of extraction and higher solubility of $\mathrm{SC}-\mathrm{CO}_{2}$. Results are comparable with the findings reported for bioactivity of Moringa oleifera by Vijay and Samrot, (2010).

\section{Conclusion}

Significant variation in the extraction yield, efficiency, physico-chemical composition, nutritional, antinutritional and bioactivity was observed in the Moringa seed kernel oil obtained by different extraction methods. The oil yield and efficiency obtained from $\mathrm{SC}-\mathrm{CO}_{2}$ was higher compared to that of the solvent extraction $(37.76 \mathrm{~g} / 100 \mathrm{~g}$ and $98.43 \%$ ), but much higher than the soxhlet extracted oil (29.12 g/100g and $76.29 \%$ ). Additionally, the bioactive components present in the $\mathrm{SC}-\mathrm{CO}_{2}$ extracted oil was observed to be not thermally amended (14 compounds) as contrast to the soxhlet (4 compounds) and solvent extracted oils (8 compounds). The antimicrobial activity of $\mathrm{SC}-\mathrm{CO}_{2}$ extracted oil against B. subtilis, S. aureus, E. coli, $P$. aeruginosa, Mucor species and Aspergillus species were higher than that of the other two extraction methods. Ultimatly, $\mathrm{SC}-\mathrm{CO}_{2}$ extracted oil had the elevated antioxidant activity $(83.80 \pm 0.02 \mu \mathrm{g} / \mathrm{mL})$ compared to conventional extraction methods. In overall, $\mathrm{SC}-\mathrm{CO}_{2}$ extraction method found to be a promising technology for extracting oil from moringa seed kernels with budding approches in food as a preservative with antimicrobial and antioxidant activities.

\section{ACKNOWLEDGMENTS}

The authors acknowledge their heartfelt gratitude to the University of Agricultural Sciences, Raichur, Karnataka (India) for the financial support extended for conducting the present investigation.

\section{REFERENCES}

Abalaka, M.E., Daniyan, S.Y., Oyeleke1, S.B. and Adeyemo, S.O. (2012). The antibacterial evaluation of
Moringa oleifera leaf extracts on selected bacterial pathogens. J. Microbiology Res. 2(2): 1-4.

Abdulkarim, S.M., Long, K., Lai, O.M., Muhammad, S.K.S. and Ghazali, H.M. (2005). Some physico-chemical properties of Moringa oleifera seed oil extracted using solvent and aqueous enzymatic methods. J. Food Chem. 93(1): 253-263.

Abdulkarim, S.M., Long, K., Lai, O.M., Muhammad, S.K.S. and Ghazali, H.M. (2009). Physico-chemical properties of Moringa oleifera seed oil extracted using solvent and aqueous enzymatic methods. J. Food. Chem. 98(1): 135 -146 .

Adejumo, B.A. and Abayomi, D. A. (2012). Effect of moisture content on some physical properties of Moringa oleifera seed. J. Agric. Veterinary. Sci. 1(5): 12-21.

Adejumo, B.A., Alakowe, A.T and Obi, D.E. (2013). Effect of heat treatment on the characteristics and oil yield of Moringa oleifera seeds. Int. J. Eng. Sci. 2 (1): 232-239.

Adesugen, S.A., Elechi, N.A and Coker, H.A.B. (2008). Antioxidants activity of methanolic extract of Sapium elliticum. Pak. J. Biol. Sci. 11: 453-457.

Ali, N. (1991). Applications of solvent extraction: a summary. Buletin FKKKSA. 5: 40-46.

Anhwange, B.A., Ajibola, V.O. and Oniye, S.J. (2004). Chemical studies of the seeds of Moringa oleifera (Lam) and detarium microcarpum (Guill and Sperr). $J$. Biol. Sci. 4(2): 711-715.

Anwar, F., Syeda, N.Z and Umer, R. (2006). Characterization of Moringa oleifera seed oil from drought and irrigated regions of Punjab, Pakistan. Pak. J. Nutrition. 57 (20): 160-168.

AOAC. (1990), Official methods of analysis of the Association of Official Analytical Chemists. $14^{\text {th }}$ Ed, Arlington.

Asokkumar, K.M., Maheswari, A.T., Sivashanmugam, V., Devi, S.N., Subhashini and Ravi, T.K. (2009). Free radical scavenging and antioxidant activity of Glinus oppositifolius (carpet weed) using different in-vitro assay systems. J. Pharmaceut. Biol. 47(1): 474-482.

Bauer, A.W., Kibry, W.M., Sherris, M. and Turk, M. (1996). Antibiotic suceptibality testing by a standardized single disc method. Am. J. Clin. Pathol. 45(1): 493-496.

Belewu, M.A., Adekola, F.A., Adebayo, G.B., Ameen, O.M., Muhammed, N.O., Olaniyan, A.M., Adekola, O.F. and Musa, A.K. (2010). Physico-chemical characteristics of oil and bio-diesel from Nigerian and Indian Jatropha curcas seeds. Int. J. Bio. Chem. Sci. 4(2): 524 -529 .

Bhatnagar, A.S. and Krishna, A.G. (2013). Natural antioxidants of the Jaffna variety of Moringa Oleifera seed oil of Indian origin as compared to other vegetable oils. $J$. Gresaa aceites. 64 (5): 537-545.

Bukar, A., Uba, A. and Oyeyi, T.I. (2010). Antimicrobial profile of Moringa oleifera extracts against some food borne microorganisms. Bayero J. Pure Applied Sci. 3 (1): 43-48.

Cakir, A., Kordali, S., Zengin, H., Izumi, S. H. and Hirata, T. (2004). Composition and antifungal activity of essential oils isolated from Hypericum hussopifolium and $H$. heterrophyllum. J. Flavour Frag. 19(1): 62-68.

Cho, Y.S., Lee, Y.S. and Rhee, C. (2010). Edible oxygen barrier bilayer film pouches from corn zein and soy protein isolate for olive oil packaging. J. Food Sci. Technol. 43 (4): 1234-1239.

Couto, R.M., Fernandes, J.M., Silva, D. and Simoes, P.C. 
(2009). Supercritical fluid extraction of lipids from spent coffee grounds. J. Supercrit. Fluids. 51(1): 159166.

Da Porto, C., Decorti, D. and Kikic, I. (2009). Flavour compounds of Lavandula angustifolia L. to use in food manufacturing: comparison of three different extraction methods. Food Chem. 112_1072-1078.

Danh, L.T., Wijngaardena, C., Mammucaria, R., Cox, J. and Foster, N.R. (2011). Comparison of rosemary extraction by supercritical carbon dioxide and hydrodistillation. Int. Conference on Process Intensification for Sustainable Chemical Industries. Beijing, China, 27-28.

Dauqan, E., Sani, H.A., Abdullah, A., Muhamad, H. and Top, A.G.M., (2011a). Vitamin E and Beta carotene composition in four different vegetable oils. Am. J. Appl. Sci. 8 (5): 407-412.

Dauqan, E.M.A., Sani, H.A., Abdullah, A. and Kasim, Z.M., (2011b). Fatty acids composition of four different vegetable oils (Red palm olein, Palm olein, Corn oil and Coconut oil) by gas chromatography. $2^{\text {nd }}$ Int. Conf. on Chemistry and Chemical Engg. IACSIT Press, Singapore.

Denny, E.F.K. (1988). Steam distillation of the subcutaneous essential oils. Flavours and fragrances: a word perspective. Amsterdam: Elsevier Science.

Enwa, F.O., Omojate, C.G. and Adonu, C.C. (2013). A review on the phytochemical profile and the antibacterial susceptibility pattern of some clinical isolates to the ethanolic leaves extract of Moringa oleifera. Int. J. Advanced Res. 1 (5): 226-238.

FAO/WHO. (2009). Report of the $21^{\text {st }}$ session of the codex alimentarius committee on fats and oils. Kola Kinabalu, Malaysia. 16-20, February.

Inuwa, H.M., Aina, V.O., Gabi, B.I., Aimola and Toyin. (2011). A comparative determination of antinutritional factors in groundnut oil and palm oil. Advance J. Food Sci. Technol. 3(4): 275-279.

Jaffe, C.S. (2003). Analytical Chemistry of Food. Blackie Academic and Professional. New York, 1: 200.

Liza, M.S., Abdul, R.R., Mandana, B., Jinap, S., Rahmat A., Zaidul, I.S. M and Hamid, A. (2010). Supercritical carbon dioxide extraction of bioactive flavonoid from Strobilanthes crispus (Pecah Kaca). J. Food Bioprod. Process. 88: 319-326.

Lucas, G.M. and Markaka, P. (1975). Phytic acid and other phosphrous compounds of bean (Phaseolus vugaris). J. Agric. Ed. Chem. 23(2): 13-15.

Mahadkar, S., Valvi, S. and Jadhav, V. (2013). Gas chromatography mass spectroscopic analysis of some bioactive compounds from five medicinally relevant wild edible plants. Asian J. Pharma. Clinical. Res. 1 (6): 1-5.

Malapit, C.A. (2010). Report on the extraction of moringa oil from moringa oil seeds. J. Lipid. Sci. 1(1): 1-5.

Mani, S., Jaya, S. and Vadivambal, R. (2007). Optimization of solvent extraction of Moringa (Moringa oleifera) seed kernel oil using response surface methodology. $J$. Fd. Bioprod. Processing. 85(4): 328-335.

Mbah, B.O., Eme, P.E. and Ogbusu, O.F. (2012). Effect of cooking methods (Boiling and Roasting) on nutrients and anti-nutrients content of Moringa oleifera seeds. Pak. J. nutrition. 11(3): 211-215.

Middleton, E.J., Kandaswami, C. and Theoharides. (2000). The effects of pant flavonoids on mammalian cell: Im- plications for inflammation heart disease cancer. $J$. Pharmacol. Rev. 52(1): 673-751.

Nabasree, D. and Bratati, D. (2007). Antioxidant activities of some leafy vegetables of India-A comparative study. $J$. Food Chem. 101(3): 471-474.

Nguyen, H.N., Gaspillo, P.D., Maridable, J.B., Malaluan, R.M., Hinode, H., Salim, C. and Huynh, H. K.P. (2011). Extraction of oil from Moringa oleifera kernels using supercritical carbon dioxide with ethanol for pretreatment: Optimization of the extraction process. J. Chem. Eng. Proc. 50(1): 1207-1213.

Nilani, P., Pinaka, K.M, Damodaran, P.D.B. and Jayaprakash, M.R. (2012). Anthelmintic activity of Moringa oleifera seed oil- validation of traditional use. $J$. $A d v$. Sci. Res. 3(2): 65-66.

Ogbunugafor, H.A., Eneh, F.U., Ozumba, A.N., Ezikpe, I., Okpuzor, J., Igwilo, I.O., Adenekan, S.O. and Onyekwelu, O.A. (2011). Physico-chemical and antioxidant properties of Moringa oleifera seed oil. Pak. J. Nutrition. 10(5): 409-414.

Olawale, S.A. (2012). Solid-liquid extraction of oils of African elemi's (Canarium schweinfurthii's) fruit. J. Agric. Eng Int. 14(2): 155-172.

Oliveira, D.A., Angonese, M. and Ferreira, S.R.S. (2013). Supercritical fluid extraction of passion fruit seeds and its processing residue (cake). III Iberoamerican Conference on Supercritical Fluids Cartagena de Indias (Colombia). 12-22.

Oluduro, B.I., Aderiye, J.D., Connolly, E.T., Akintayo, O and Famurew, A.D. (2010). Characterization and antimicrobial activity of 4 -( $\alpha$-D-Glucopyranosyl- $1 \rightarrow 4-\alpha-\mathrm{L}$ -rhamnopyranosyloxy)-benzyl thiocarboxamide; a Novel Bioactive Compound from Moringa oleifera seed extract. J. Folia Microbiol. 55 (5): 422-426.

Orhevba, B.A., Sunmonu, M.O. and Iwunze, H.I. (2013). Extraction and characterization of Moringa oleifera seed oil. J. Food. Dairy Technol. 1 (1): 125-138.

Palafox, J.O., Navarrete, A., Julio, C., Rivero, S., Atoche, C.R., Escoffie, P.A., Antonio, J. and Uribe, R. (2012). Extraction and characterization of oil from Moringa oleifera using supercritical $\mathrm{CO}_{2}$ and traditional solvents. Am. J. Anal. Chem. 3(1): 946-949.

Petukhov, I., Malcolmson, L.J., Przybylski, R. and Armstrong, L. (1999). Frying performance of genetically modified canola oils. J. Am. Oil chemist's society. 76(1): 627-632.

Prabhu, K., Murugan, K., kumar, A., Ramasubramanian, N. and Bragadeeswaran, S. (2011). Larvicidal and repellent potential of Moringa oleifera against malarial vector, Anopheles stephensi Liston (Insecta: Diptera: $\mathrm{Cu}$ licidae). Asian Pacif. J. Trop. Biomed. 1(2): 124-129.

Pradhan, R.C.A., Meda, B.V., Rout, P.K.A., Naik, S.A., Ajay, K. and Dalai, C. (2010). Supercritical $\mathrm{CO}_{2}$ extraction of fatty oil from flaxseed and comparison with screw press expression and solvent extraction processes. J. Food Engg. 98(1): 393-397.

Premi, M. and Sharma, H. K. (2013). Oil extraction optimization and kinetics from Moringa oleifera (PKM 1) seeds. Int. J. Agric. Fd Sci. Technol. (4)4: 371-378.

Rahman, I.M.M., Nazimuddin, S.B.M., Zinnat, A.B., Rahma, M.A. and Hasegawa, H. (2012). Physicochemical properties of Moringa oleifera Lam. seed oil of the indigenous-cultivar of Bangladesh, Int. Food Res. 19(2): 503- 
508.

Razazadeh, S.H., Baha-Aldini, B.Z.B.F., Vatanara, A., Behbahani, B., Rouholamini, N.A., Maleky-Doozzadeh, M., Yarigar-Ravesh, M. and Pirali, H.M. (2008). Comparison of super critical fluid extraction and hydrodistillation methods on lavanders essential oil composition and yield. J. Medicinal Plants. 7: 63-68.

Sabir, S.M., Hayat, I. and Gardezi, S.D.A. (2003). Estimation of sterols in edible fats and oils. Pk. J. Nuti. 2(3): 178-181.

Suarez, M., Entenza, J.M. and Dorries, C. (2003). Expression of a plant derived peptide harbouring water cleaning and antimicrobial activities. J. Biotechnol. Bioeng. 81 (1): $13-20$.

Talreja, T. (2010). Screening of crude extract of flavonoids of Moringa oleifera against bacterial and fungal pathogen. J. Phytology. 2(11): 31-35.

Tint, T.K. and Mya, M. (2009). Production of biodiesel from Jatropha oil (Jatropha curcas) in pilot plant. World Academy of Sci. Engg. Technol. 477-480.
Topal, U., Sasaki, M., Goto, M. and Otles, S. (2008). Chemical compositions and antioxidant properties of essential oils from nine species of Turkish plants obtained by supercritical carbon dioxide extraction and steam distillation. Int. J. Food Sci. Nutrition. 59: 619-634.

Tsaknis, S., Lalas, S., Gergis, V., Dourtoglou, V. and Spiliotis, V. (1999). Characterization of Moringa oleifera variety mbololo seed oil of Kenya. J. Agric. Fd Chem. 47(2): 4495-4499.

Vijay, A. and Samrot, V. (2010). Bioactivity of moringa oleifera. J. Medicinal Plants. Res. 1(2):10-15.

Wang, J., Cui, H., Wei, S., Zhuo1, S., Wang, L., Li, Z. and Yi, W. (2010). Separation of biomass pyrolysis oil by supercritical $\mathrm{CO}_{2}$ extraction. J. Smart Grid and Renewable Energy. 1(1): 98-107.

Zhao, S. and Zhang, D. (2013). A parametric study of supercritical carbon dioxide extraction of oil from Moringa oleifera seeds using a response surface methodology. $J$. Separation and Purification Technol. 113(5): 9-17. 